\title{
From a Text to Practice and Back Again. Making Knowledge(s) Work for Participatory Budgeting in Poland
}

\begin{abstract}
The purpose of this paper is to provide an insight into practices of producing and translating knowledge that is intended to improve the work of participatory budgeting in Poland. From the onset, the knowledge processes described are no flat or transparent accounts. Rather, they should be perceived as profoundly performative, that is, entailing several translations of various types of knowledge together with the very conditions in which they are supposed to operate. The initially launched knowledges are supposed to eventually turn into a fairly coherent, non-imposing, well-embedded framework for thinking and acting. The success is then largely dependent on how knowledges are being inscribed, enacted and embodied in a complex and dynamic environment.
\end{abstract}

KEYWORDS: knowledge performativity, knowledge translations, inscribed, enacted, embodied knowledges, participatory budgeting

RECEIVED 16 May 2016; ACCEPTED 9 January 2017.

\section{INTRODUCTION}

Participatory budgeting has come to be one of the most popular mechanisms of civic engagement in Poland. The number of participatory budgeting initiatives in municipalities has surged from the first one launched in 2011 to a total of over 180 carried out until 2016. ${ }^{2}$ Standards for the Processes of Participatory Budgeting in Poland defines it as a tool that grants citizens with real power to co-decide on how to allocate a certain part of their local budget $(2014$, p. 8$)$. Although there is no universally accepted formal procedure for participatory budgeting, there are some stages or rules that are broadly accepted as essential to it. In a basic sense, participatory budget should allow community members to discuss and identify the local needs and priorities, then to propose responding activities and projects and, finally, to decide which ones are to be realised. The last stage often (but not necessarily) consists in election by vote. The outcomes are binding for the local authorities. Importantly, it is also assumed that each participatory budget should be well adjusted to the local conditions and needs, beginning from its amount proportionate to a regular budget to the very mechanism of deciding which of the proposed activities would be implemented. All in all, a participatory budget can be a powerful tool of social inclusion and accountability yet, at the same time, it carries a lot of risk. Shortly after its first appearance in Poland, it has come to be obvious that in many places, participatory budgeting works more alike to a plebiscite than a process fostering deliberation and civic engagement (see Sześciło, 2015).

This paper analyses how various types of knowledge are being produced and translated in order to become part of public administration daily work and thus act towards the reinforcement of civic participation and civil society in Poland. Therefore, participatory budgeting will not be the object of interest as such; rather, it makes for the case by means of which the knowledge processes at stake will be presented.

The argument is built on an extensive ethnographic case-study research conducted in a Polish non-governmental organisation (NGO) dedicated to building civil society and improving the quality of public life - The Unit for Social Research and Innovation 'Shipyard' (later called Shipyard). Although civic participation has been one of its key areas of activity for several years now, the article largely concerns a project focusing on the participatory budgeting in Poland. According to the grant proposal, the overall aim of the

\footnotetext{
1 Aleksandra Koltun: Maria Curie-Skłodowska University, Poland. Email : aleksandra.koltun@gmail.com

2 Data according to The Unit for Social Research and Innovation 'Shipyard'; http://bp.partycypacjaobywatelska.pl/porownywarka-budzetow/. Participatory budgeting is not restricted to municipalities, but in Poland, such initiatives are by far most common.
} 
project under scrutiny was to 'reinforce the local government, organisations and active citizens engaged in realisation of participatory budgeting in their towns by ensuring them with tools and knowledge essential to gradually improve these processes' (grant proposal, p. 3). The project included a variety of activities consisting in producing and disseminating diverse knowledges on what a proper participatory budget was and how it could be launched. What served as a point of reference throughout the whole process was a publication - Standards for the Processes of Participatory Budgeting in Poland (further referred to as Standards...), announced by Shipyard for the first time in 2014. This document proposed a model of participatory budgeting that met the formal criteria and also allowed for accommodations according to the local needs and specificities.

The main point of this article is to show that knowledges that are supposed to work smoothly for various actors in the field and, thus, bring some change into reality should be understood in terms of a performative process, rather than a well-defined, static entity to be discovered and implemented. The model of participatory budgeting proposed in Standards... works upon a package of diversified knowledges. Far from being a neutral, descriptive account of reality, the knowledge package encompasses a body of conceptual ideas and practical ways of conduct, together with an essential axiological backdrop. The effectiveness of such knowledge package is secured in the course of complex, multifarious translations. In line with the framework proposed by Richard Freeman and Steve Sturdy (2014), the translations consist in embodying knowledges so that they become part of people's worldviews and practices, enacting knowledges in context-specific situations, as well as inscribing these knowledges into further documents and tools in a manner that they become stable and reproducible. However, in the case presented here, translations consist not only in performing the knowledge package but also in restructuring of the very setting so that it becomes suitable for the package. In other words, Shipyard's task is to disseminate the model as well as to promote some broader changes in municipalities' institutional performance and communication with the citizens. Eventually, it seems that what can be judged a favourable outcome of the whole process is making the initially 'crude' knowledge package from Standards... invisible, natural and taken-for-granted.

The article begins with an overview of the conceptual framework adopted. I pay special attention to grounding the knowledge performativity thesis. Although my background is primarily in Science and Technology Studies (STS), the argument can be also situated within the field of policy studies. Especially, the works of Freeman and Sturdy on knowledge processes in policy work (2015) allow refining the STS import. Next, I provide some more detailed information on the field and the methodology of the study. In the third part of the paper, I present the main findings of my inquiry together with a range of examples from the field. I start with a brief introduction into how the knowledge package is created and launched within Standards... Then, a section on translations follows. It includes some detailed examples of how knowledge inscriptions, embodiments and enactments take place. Finally, I provide some concluding remarks concerning an overall course of the process and its implications for the knowledge performativity thesis.

\section{THE KNOWLEDGE PERFORMATIVITY THESIS AND ITS POSITION WITHIN POLICY STUDIES}

This paper can be read in two ways. First and foremost, it is an argument in favour of a specific understanding of knowledge that is dynamic, collective and primarily performative. However, it can also be considered an empirically founded illustration of the field in which the third sector meets the state in order to bring about some improvement by means of putting various knowledges to work. In the following text, I present the key conceptions that have inspired this paper: Science and Technology Studies and the embodied/ enacted/inscribed knowledges framework by Freeman and Sturdy. Then I situate this piece of work within the field of policy studies, specifically those which conceptualise policy in terms of translation and negotiation.

Analysing knowledge in terms of performativity is supposed to draw attention to its specific, profoundly transformative character rather than its content composed of adequate descriptions of the world. This approach can be distinguished from other philosophical stances towards knowledge, especially those which emphasise the informative aspect of knowledge and examine it as true or false upon formal and logical procedures. In the simplest sense, the knowledge performativity thesis refers to a renowned conception of speech acts by John L. Austin (1975). Knowledge considered as performative has the capability of 'doing what it states', whereas the more traditional ways of understanding knowledge can be compared to Austin's concept of constative utterances (which describe the world and can be judged true or false).

Apart from Austin's conception, the performativity standpoint adopted in this paper is greatly inspired with the works of authors identified with STS, such as Karen Barad (2003), Bruno Latour (1983; 1999), John Law (2004; 2007), Andrew Pickering (1992; 
Pickering \& Stephanides, 1992) and Joseph Rouse (2014). In general, STS depart from a traditional, positivist vision of knowledge and science for the sake of more practice-oriented, constructivist account of what is happening in various sites of knowledge production. The shift can be summarised as one from understanding knowledge as a well-defined, fixed propositional content that represents the world, and can be possessed or applied, towards a vision highlighting diverse social, discursive and material practices of 'knowing' (see Rouse, 2014; Wehling, 2006). Instead of brilliant, disembodied, rational minds and methodologies striving for objectivity, the focus is placed on collective work of humans and non-humans. The outcome is producing objects, facts about these objects and a properly reconfigured sector of reality. As Latour explains, just like there are no trains without railway tracks, there can be no scientific fact without a well-accommodated, 'laboratorised' setting (Latour, 1983). All in all, even though some of the abovementioned authors do not apply the notion of performativity in a straightforward manner, their works elaborate a vision of knowledge as a productive, open-ended, heterogeneous process (for more see Kołtun, 2015).

One of the central concepts appearing in this paper - translation - is applied largely in line with actor-network theory. I rely on its understanding in terms of movement and transformation rather than solely the act of linking diverse elements together (see Callon 1986; Latour 1983, 1999). As Law states, translations are possible only by means of a certain betrayal - carving the agents, shifting the interests of all sides and eventually making them common (Law, 2007, p. 5). Therefore, the notion of translation welcomes the profoundly processual and often chaotic way in which the knowledge package from Standards... is being disseminated and applied. It also highlights the fact that no one is ever in full control of the whole knowledge process: quite often the results of actions differ from those planned or become apparent in odd circumstances.

Knowledge translations do not take place in vacuum or in a fully contingent, arbitrary manner. They work against a setting that is complex and fluid and requires constant actualisations of what is 'there' at the moment. For this reason, I choose to replace the term 'setting' with the notion of hinterland, defined by Law as a certain topography of possibilities and constraints for translations (Law, 2004, p. 34). This means that in order to succeed, the knowledge package has to be installed against a properly accommodated hinterland of existing practices, beliefs, devices, theories, institutions and so on. Importantly, if we take into account this twofold movement of the knowledge package - as being translated together with its hinterland - then it becomes extremely difficult, if not impossible to judge what progress is. Certainly, any externally measured, objectivised evaluations hardly apply here.

The conceptual scheme has been also refined with a framework elaborated by Richard Freeman and Steve Sturdy (2015a). Their work, reflecting upon broadly understood knowledges in policy work, can be considered consonant with STS. Knowledge movements are also conceptualised in terms of translations, highlighting that 'the content and meaning of knowledge is inevitably transformed as it is transferred from bodies into documents' (Freeman \& Sturdy, 2015b, p. 204; see also Freeman, 2009).

Freeman and Sturdy take notice of three interrelated phases or forms of knowledge: embodied, inscribed and enacted. The embodied knowledge refers to what Ryle called 'knowledge what' and 'knowledge how' (1949), thus including acquired theories and conceptual ideas, personal experiences, skills and so on. Embodied knowledge can be easily actualised and stays practice driven and mobile, yet, at the same time, it is prone to oblivion and misrepresentation. No matter how common some experiences or skills appear, embodied knowledge is always attached to a concrete individual. Moreover, according to Freeman and Sturdy, knowledges can be inscribed in various documents and devices. Inscriptions generally allow more stabilisation and coordination of various actors across time and space. Apart from granting intersubjectivity, knowledges inscribed work in a fairly persistent but silent and effective manner. Finally, Freeman and Sturdy argue that knowledges have to be enacted in the course of actions and debates. Only enactments make the embodied and inscribed knowledges alive, working. They are most elusive and context bound, yet, eventually, they make for the gist of knowledge processes investigated in this paper. Altogether, the framework proposed by Freeman and Sturdy is especially apt for looking into real-world settings in which it is impossible to distinguish unequivocally between the propositional and the tacit as well as between the practical and the material aspect of knowing.

The argument put forward in this paper, although arising primarily from broadly understood studies of knowledge production, can also be linked to the recent debates running within policy studies. It provides an insight into the so-called policy work, understood in line with $\mathrm{Hal}$ Colebatch and collaborators as 'how participants [political leaders, bureaucrats, experts, interest group representatives, etc. - A.K.] bring their diverse forms of knowledge to bear on policy questions but how this work is done is something that is learned from practice rather than from study' (Colebatch, Hoppe, \& Noordergraaf, 2010, p. 12). The research presented below deals with a fairly particular space of negotiations between an expert NGO and public administration in the process of elaborating and implementing the standards of conduct for civil servants who, ultimately, should bring about a positive change in their communication with people. Also, this investigation reconstructs the standpoint represented by the NGO and its collaborators, with only secondary insights from the civil servants or the citizens. 
Furthermore, John Clarke and collaborators conceive of the notion of policy in terms of translations and assemblage (Clarke, Bainton, Lendvai, \& Stubbs, 2015). The authors highlight that their approach encourages to 'explore more fluid, dynamic and messy processes' (Clarke et al., 2015, p. 16). Thus they put into question the meanings ascribed and created in policies, the space and time they actively rework as well as their performative dimension (Clarke et al., 2015, p. 16-32). In a similar vein to the above reformulations of the notion of knowledge, policy is no more a single, static entity that only requires an act of neutral, linear transfer. Rather, it is assembled from a variety of elements that can give surprising effects, are always unfinished and are prone to change.

Finally, given that the empirical background of this paper pertains to participatory budgeting, it can be read as a certain commentary to how the policy itself spreads and transforms across times and settings. Jamie Peck and Nik Theodore describe participatory budgeting as one the so-called 'fast policies' (along with conditional cash transfers; Peck \& Theodore, 2015). In accordance with the authors referred to above, Peck and Theodore explore how participatory budgeting travels and is 'constructed through policy networks, each of which possesses specific institutional, ideational, and ideological characteristics' (Peck \& Theodore, 2015, pp. xxiv-xxv). So far, Polish experiences confirm their insights. Various experts have pointed that participatory budgeting in most Polish municipalities allows little engagement from the citizens, channelling it to the stage of voting, whilst leaving few opportunities to effectively deliberate on the shape of procedure itself or the strategic issues, including the major government spending (see Kębłowski, 2014; Szaranowicz-Kusz, 2016; Sześciło, 2015). It seems then that the dominant, local standard for Poland is short of the politicised, radical face characteristic of the Porto Allegre original. Such model is what Peck and Theodore describe as a fast, 'pasteurised' or 'synthesised' version of participatory budgeting.

\section{THE FIELD AND RESEARCH METHODOLOGY}

The argument presented in this paper draws on a qualitative study aiming to provide insight into practices of producing and translating knowledges for a social change. The research methodology is a single case study with embedded units (Yin, 2003), where The Unit for Social Research and Innovation 'Shipyard' represents the main case whilst two specific projects make for the 'embedded units'.

As an NGO, Shipyard is largely dedicated to building civil society, improving the quality of public life and modernising the state. Since its start in 2009, Shipyard's work could be situated at the intersection of public administration, the third sector and academic social sciences. Apart from civic participation, its areas of interest include social innovations, research and evaluation, and the socalled bringing together of knowledge and practice. Therefore, the scope of activities is broad and diversified, ranging from doing research and evaluation of diverse programmes and procedures; providing expertise on policy management; designing solutions and tools for NGOs, citizens and officials; advising on how to introduce certain mechanisms; to practising and experimenting on them in concrete settings. The majority of projects and activities is funded in open competitions organised by the state (on various tiers of public administration) and in international programmes. Importantly, the declared logic for Shipyard's projects and activities is to bring together reflection ('think-tank'), action ('do-tank'), elaboration of systemic solutions and education.

Depending on the area of activity, Shipyard members collaborate on a daily basis with, amongst others, representatives of ministries as well as local governments, politicians and activists, other expert and non-expert NGOs, academicians and specialists in various disciplines (from urban planning to cognitive sciences) and citizens. At the same time, Shipyard takes advantage of various international contacts and partnerships with several organisations and institutions that deal with similar topics. The projects are often carried out in close collaborations with experts from abroad, who provide their knowledges in live meetings and through summoned works.

Within a couple of years of its operation, Shipyard has developed a fairly specific relationship with the state representatives, above all public administration officials. On the one hand, it has come to be known as an expert in the field of civic participation, both as a provider of reliable and useful knowledge and a skilled guide in practical matters. On the other hand, as Shipyard members admit, they have gained status of a 'friendly' partner: one who will rather give a helping hand than scold or meticulously look for mistakes and then alarm the media. Asked if such cooperative strategy is better than the other, one of my respondents explained that they work well together, as complimentary.

Shipyard was chosen as the research case in the course of preliminary desk-research analysis. Out of a great range of expert organisations dealing with broadly understood knowledge processes, it stood out for two vital reasons. First, it declared interest in translating academic concepts into practical expertise in order to diagnose needs and solve hands-on problems. Second, knowledge production and dissemination made for one of the main fields of its activity in several projects. 
As mentioned, the study has been carried out alongside two projects selected in agreement with Shipyard members as those which were mostly pertinent to research questions. Both projects belonged to the civic participation area but were realised separately and came to an end in 2016. Their objectives pertained to improving the mechanism of participatory budgeting or public consultations; the latter, however, will not be scrutinised in this paper. The activities realised within both projects included, amongst others, seminars and workshops for practitioners, research, preparing publications with guidelines and tips as well as on-site advising on how to implement the procedure in selected municipalities.

Overall, the research took two years. Data collection included a range of techniques, such as overt participant observations and non-participant observation during various working meetings and official project activities, in-depth and semi-structured interviews with Shipyard members as well an extensive study of official documents, working papers, informal notes and so on produced by Shipyard, its collaborators and the beneficiaries of the projects (e.g. municipalities, other NGOs). Moreover, once in a while I presented the working conclusions from my research during meetings open to all Shipyard members. These greatly contributed to refining the research questions and findings.

The data was analysed largely in accordance with the constructivist grounded theory (see Charmaz, 2006). In the first place, I conducted open coding of observations, assisted with close examination of photographs. Next, I shifted to open, selective and axial coding of the interviews and documents. Alongside coding I was writing numerous memos. This order of analyses was driven by the Latourian order to 'follow the actors' (Latour, 2005, p. 12). I specifically focused on the actual practices and events in the field whilst treating discursive accounts and interpretations as a source of new research questions and triangulation of the heretofore conclusions. My sampling was guided by developing hypotheses and research questions, however, always remaining in close interaction with the conceptual framework of knowledge performativity.

Accordingly, the standpoint presented here is primarily of Shipyard and its collaborators. For the principle objective of my study - looking into how knowledges are produced and translated - it was crucial to reconstruct the practices, perspectives and justifications of the main actor in the field, that is, Shipyard and its collaborators. This is not to say that the beneficiaries and participants of various activities were completely out of my sight. I did not conduct interviews with them or run observations independent from Shipyard's activities. Such inquiry would certainly enrich the conclusions presented here, yet, for that time, it was out of scope for both substantive and organisational reasons. However, I paid close attention to the reactions, interactions and evaluations of the participants of various project activities. Also, a lot of effort from Shipyard members was directed towards making the project more suitable and attractive for the stakeholders (including continuous external evaluations conveying their opinions and needs). This way the projects' beneficiaries were constantly, yet indirectly, present in my research field.

As regards my position in Shipyard, from the start, I was acting as an independent researcher, avoiding any commitment to providing anyhow useful or evaluative knowledge for the sake of the organisation. My participatory observations entailed some voluntary work on my side. These were, however, minor, pre-defined tasks, such as gathering data in desk research, reminding municipalities to fill in questionnaires and transferring content from one website to another. This way I wanted to at least minimally contribute to the processes I was observing, yet, at the same time, avoid major influence over the directions or forms of Shipyard's action. Also, as an NGO, Shipyard made almost no restrictions for me doing observations or accessing documents. The beneficiaries of the projects who met me on various occasions throughout the projects were informed by Shipyard members of the reasons for my presence. Most probably, I was perceived as another Shipyard representative - maybe not very active, but in some ways collaborating with them.

The conclusions presented below stem from analyses of data gathered within both projects investigated. However, for the sake of clarity and conciseness, the examples presented below pertain solely to the area of participatory budgeting. It is also important to stress again that the procedure of participatory budgeting as such is not the object of my interest. Rather, it forms a part of my research field, being the 'object' of knowledges that I look into.

\section{THE MAKING-UP OF A BASE DOCUMENT}

In 2014, Shipyard publishes Standards for the Processes of Participatory Budgeting in Poland. Its appearance is the moment in which Shipyard intensifies endeavours to improve quality budgeting but, certainly, does not embark upon them as new. Standards... draws upon the already available knowledges and will remain central to the knowledge processes that follow in the project investigated. One 
of Shipyard members would claim that throughout the project it acts as 'an axiological spine' or 'spirit'. Therefore, Standards... will be called further 'a base document'.

As Shipyard members recall, the decision to prepare the publication resulted from an observable surge in number of municipalities that introduced participatory budgeting, usually with little assistance or familiarity with the procedure. Thus, there was a growing demand for information and practical guidance. At the same time, many practitioners representing both NGOs and the local offices started to express the need to settle what a participatory budget was and how it should work. From the technical point of view, the release of Standards... was an unplanned but welcomed finishing point of a long-standing project dealing with civic participation, prior to the one examined here. It turned out that there were enough savings in the project to undertake some extra but desirable actions.

In other words, a 'window of opportunity' opened in the hinterland: a demand for practice-oriented guidance with available money and resources at hand. Importantly, there was also an organisation capable of recognising this opportunity and hosting the process of creating the document. Shipyard already enjoyed reputation of an expert in the field of civic participation and a cooperative partner, amongst both officials and other NGOs. This favourable position has originated from neither an accident nor a planned strategy but several previous undertakings and events - jobs done, relationships started, experiences gained. Standards... was created collectively in a series of workshops and further discussions as well as collaborative writing. Shipyard purposefully engaged in this process the so-called theoreticians and practitioners, that is, representatives of NGOs, local governments and ministries, as well as the academia. The document provides, amongst others, a definition of participatory budgeting and its crucial ideas and aims, a description of nine stages that make for the procedure, a selection of the so-called challenges and a list of useful publications and references. The list includes a range of reports, published expert opinions and analyses and overviews of participatory budgeting from Poland and abroad.

Clearly, at the point of embarking upon creation of Standards..., various knowledges are already at work. The contributors, from both Shipyard and other organisations, bring not only an up-to-date grasp of practical problems and available solutions but also their personal acquaintance with documents, policies and local regulations that extend far beyond a list provided in the publication. Moreover, these available inscribed and embodied knowledges are enacted and further reformulated, first in the course of live debates in working meeting and then throughout drafting and refining the text. This mobilisation of both embodied and inscribed knowledges is supposed to contribute to the quality and workability of the proposed model. Namely, it should be comprehensive, yet adaptable to local conditions; it should provide a benchmark, but remain applicable. At the same time, the collective creation of Standards... in an expert circle adds to its legitimisation and recognition amongst the intended audiences: civil servants, activists, NGO representatives.

In terms of its content, Standards... is a propositional account that, however, reveals an intrinsic orientation towards future practice. It includes an explicit determination of the 'what': a definition of participatory budgeting. Also, it has a large component intending to, possibly, propose and show the 'how' (see Ryle, 1949). The stages of procedure are described in terms of what specific actions they entail, how these actions are related to each other and what consequences they have further on. Moreover, each stage is presented in its 'minimal' and 'maximal' variant. Several ideas are illustrated with concrete tips and solutions. The ideas and possible proceedings proposed in Standards... are also located within a broad plan of values, such as common good, inclusion and civic engagement. This axiological backdrop provides a fundamental complement to the practical recommendations which, on their own, could result in merely satisficing the elemental requirements. As Shipyard members explain, a real change requires much more than that; above all, it is about value-laden beliefs and worldviews. Altogether, Standards... delivers a diversified, holistic, future-oriented propositional-practical-axiological package of knowledges.

Importantly, the knowledge package from the base document actually entails the act of performing the object-mechanism. Stating what participatory budgeting is, it implicitly marks what is not under scrutiny. For instance, the procedure of choosing projects for implementation should be open to all community members. Consequently, if projects are elected by the mayor alone or even the local council, this is no participatory budgeting. This means that some of the problems that citizens or officials find urging may actually be judged out of scope, irrelevant. Future translations of the knowledge package are, above all, about performing the defined mechanism. The principle for future translations is to construct rather than ameliorate; various ongoing issues are, at best, subjected to this primary goal.

In sum, the peculiar role of Standards... as the base document for knowledge processes under scrutiny originates from, first, the moment in which it appears (as a result of merging of previously available knowledges with some largely unpredictable circumstances 
in the hinterland); second, the way that it is created (in a process of negotiations between diverse engaged actors who represent the intended users and audiences and bring in various knowledges); and, third, the contents it carries (ideas and detailed examples of practices with recommendations, explicitly situated in a specific axiological background). The knowledge package from Standards... is well embedded and, at the same time, powerfully productive. It works upon what is pre-given yet also establishes its own definitions of what it deals with, thus delineating the field for upcoming translations. The aim of publication should be seen primarily as performing what it states rather than improving on a diagnosed field of reality.

\section{THE WORK OF TRANSLATING KNOWLEDGES}

In many cases, the work of reforming of public policies ceases right where we have just arrived: publishing a document with a proposal of amendments. It may even receive some attention, but in general, its announcement is the pinnacle of previous efforts of its authors. Differently, Standards... serve as a point of departure and a reference for still ongoing processes. Soon after that release of Standards..., Shipyard starts the project aiming to improve the mechanism of participatory budgeting in Poland. At the point, however, the knowledge package is still disconnected from the real, daily practice.

The success of knowledge process does not consist in transforming its very content, but rather translating it together with the hinterland in which it is supposed to operate. The difficulty with accomplishing translations is twofold. First of all, the knowledge package needs to stay 'the same', yet become manageable and unobtrusive. Every translation is a trade-off between comfort and oversimplification, between convenience and seriousness, between accuracy and costliness. In other words, in the end of the chain of translations, the knowledge package has to remain its propositional-practical-axiological import and avoid being constricted to a set of indicators or a playful supplement to a serious job or a painstaking burden.

Second of all, in order to translate the package effectively, Shipyard members need to recognise and mobilise the right elements of the hinterland - diverse actors, formal and informal documents, devices. Time and again, they need to re-examine where to channel their efforts so as to make the most impact. Furthermore, the hinterland changes not only for some external reasons (e.g. elections) but also as a result of the undertaken knowledge translations. Therefore, Shipyard members who deal with the knowledge package from Standards... have to constantly update their knowledges and strategies of action. Also, they need to handle particularly high levels of uncertainty for there are hardly any stable, context-independent measures of progress.

Eventually, the whole process can be compared to Latourian black-boxing (Latour, 1999, pp. 183-185). The more stabilised and extensive the network of people, documents and devices, the more black-boxed the knowledge package becomes. Throughout translations, the fact that the package is historical, and its origins are specific and context-dependent, disappears from sight. The package evolves into a part of this hinterland on which future actions are built, but which never comes to a standstill. The work of translating does not ever come to a definite end.

\section{From the base document to knowledge enactments and embodiment...}

There are certain people who seem more important to making the knowledge package successful than others: for example, civil servants and citizens are indispensable, whereas the media and politicians are regarded 'merely' influential. The translations have to engage those people who somehow stand for others (either are capable of exercising power, such as principals in offices, or advocate for large groups of interest, such as some NGOs) but, at the same time, remain 'practitioners' who will not convert the renewed mechanism into an abstract procedure. The objective is to enact and embody the knowledge package so that it transpires through people's mindsets as well as organisational cultures.

The recognition of the exact identities of actors to be engaged is hard and requires a lot of tacit, constantly updated experience. More trouble arises when we learn that no identity is established once and for all. The 'champions' sometimes lose their initial zeal (or simply quit their jobs), whilst the 'hopeless' become 'potentially successful'. Even the identity of Shipyard evolves in time, for instance, from an initial 'proprietor' or an 'author' to a 'host' that only oversees the work of a knowledge package. The recognised identity of a group of actors provides a premise for, on the one hand, recruitment and, on the other, of excluding, 'othering' (Law, 2004, pp. 83-85). Precisely, making endeavours to involve those who are entirely disinterested and disengaged (but who would 
seem to be in dire need of such assistance) is a rare choice, mainly because of its highly probable failure. Almost the same can be said about those actors who seem to be doing well on their own: they require little or no help from outside but can provide perfect evidence and exemplars of how the renewed mechanism works. Therefore, they are often invited to collaborate as partners in order to share their embodied knowledges for the benefit of project's participants. Finally, each recognised group of actors at all times needs to be addressed on its own terms of expertise, time, scope of changes proposed. In other words, the background and assumed expectations of people involved make for one of the crucial dimensions of the hinterland that need to be recognised.

In the following, I present two examples of enacting and embodying of the knowledge package. They come from a series of seminars on participatory budgets. The participants have been recruited as teams consisting of a civil servant and an NGO representative from the same municipality. The principal idea behind both variants of seminars is not only to convey the content of the knowledge package but, above all, to enact it together with the participants so that it can be embodied within their theoretical frameworks, memories, experiences and worldviews.

The majority of activities in both types of seminars is planned around a schematic model of participatory budget that appears in Standards... as a certain organising principle for narrating the whole mechanism. It shows three parallel circles divided into lines with cursors; a clear message that a participatory budget is a long-standing process with overlapping stages, rather than series of annually held, easily manageable events. As can be seen in Figure 1, the model is concise and quite telling. It should be easy to memorise, if not in detail, than at least in its circularity that stands for one of the most important aspects of the propositional content of the knowledge package from Standards... Also, the model can be conveniently reproduced on flipcharts, on posters and in presentations (see Figure 2).

Fig. 1: The model screened during a seminar for the beginners

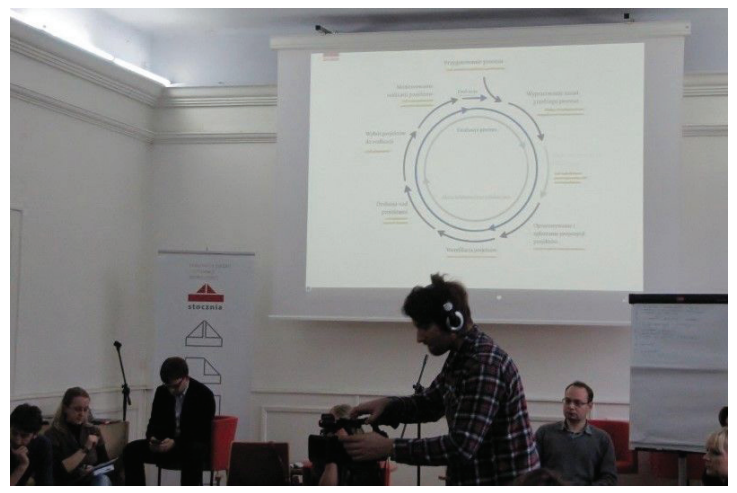

Fig. 2: The model as a working paper in an exercise on a seminar for the advanced practitioners

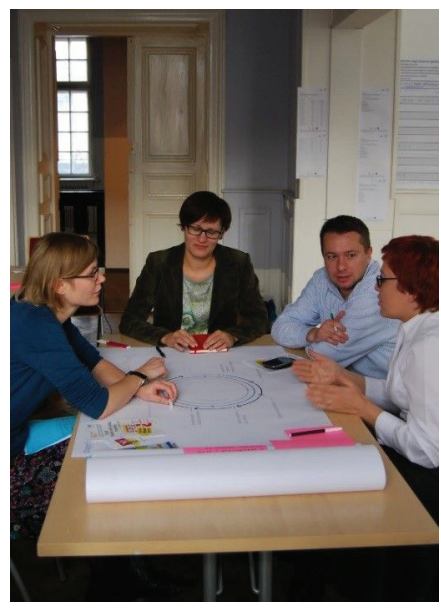


The translation of the knowledge package from Standards... into a circular model on a flipchart or screen is only the beginning. The model alone can do little good. It does convey a fundamental but certainly insufficient part of the theoretical import from the knowledge package. And so, another translation has to take place. The model becomes capable of bringing all vital knowledges only in interaction with the enacted and embodied knowledges of the participants and Shipyard moderators. This translation, however, requires a more profound recognition of the hinterland. The seminars are held in two separate variants: one for 'the advanced practitioners' and the other for 'the beginners'. Thus, the differentiation of the hinterland pertains to the knowledges that the participants assumedly bring in.

In Figure 1, we can see that the model is screened as part of a presentation. Shipyard members enact the knowledges within a rather one-sided communication process with little possible feedback or interaction from the participants. However, this is what it is supposed to happen. The beginners are believed to know little of the mechanism, and thus they primarily need an overall vision of ideas, practices and the value-laden, lasting objectives of participatory budgeting. The model comes to serve as a point of departure for, first, conveying 'what' participatory budgeting stands for; second, delivering a great range of examples of 'how' it works; and eventually, reasoning upon 'why' it does so (and 'where' it aims).

Differently, in Figure 3, the knowledges from Standards... are enacted in a far more dynamic situation in which feedback and discussion are very welcome. Supposedly, the advanced practitioners not only have an image of what a participatory budget is but also share some experiences of how it works. The hinterland in this seminar is then far more complex than in the case of the beginners. One cannot ignore the existing knowledges that participants bring in and treat them as novices. Yet, from Shipyard's point of view, their knowledges may require specific complements or advancements in concordance with the knowledge package from the base document. Precisely, the advanced practitioners need to connect their existing knowledges with the ones from Standards... in a way that, at best, these knowledges appear as right and purposeful, and available for practice. However, working upon the existing embodied knowledges of the participants carries the risk of turning the whole seminar into a sociable chit-chat of people with similar backgrounds and problems, without any point of reference or objective.

Consequently, in the 'advanced' seminar, the model of participatory budgeting is put to use as a certain guidance for activities. Shipyard moderators present it to groups of participants as an organising principle for discussing each stage of participatory budgeting as it takes place in subsequent places. Specifically, they provide explanations and justifications for certain solutions used in concrete contexts. In other words, the moderator constantly brings forward knowledges from Standards..., so that they are referred to and debated in a contextualised but orderly manner. Again, we have the 'what', the 'how' and the 'why' from the base document, but, this time, these knowledges are enacted together with the participants who also evoke their own embodied experiences and beliefs. At the same time, the moderator writes the key points generated in the discussion on a flipchart representing the model. The reason for further inscribing the enacted knowledges is that the outcomes of the activity are to be shared with the other participants.

Figure 3 presents the contextualised model originating from Standards... The embodied knowledges of Shipyard members and seminar participants have been, on the one hand, enacted in a discussion around it, on the other hand, made present and cognisable for others by means of inscribing the knowledges back into the model.

Fig. 3: The model as means for enacting the knowledge package and inscribing the embodied knowledges

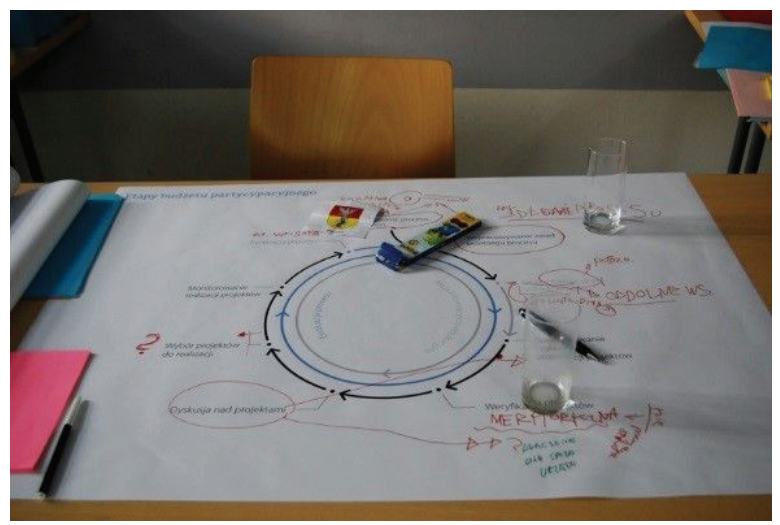


The second example of a series of translations of the knowledge package from Standards... also comes from seminars. This time the knowledge package is turned into a checklist of 20 questions. This is the first translation - making the package workable, but not oversimplified by means of deciding which of its contents are indispensable and easily determinable. The list, however, provides only a point of departure. It could well be filled in at home, encouraging to enact knowledges from Standards... in terms of a quick selfdiagnosis of each participatory budget. However, the goal is to enact the whole knowledge package in a more controllable setting. The second translation consists in placing questions from the checklist on 20 flipchart-size imprints that are pinned against the walls of the seminar room. Each poster represents one question pertaining to a specific practice from the knowledge package (see Figure 4).

Fig. 4: A poster from the checklist. The question is in the heading, with blank spaces for answers from each municipality in lines below. Giving additional information is welcome

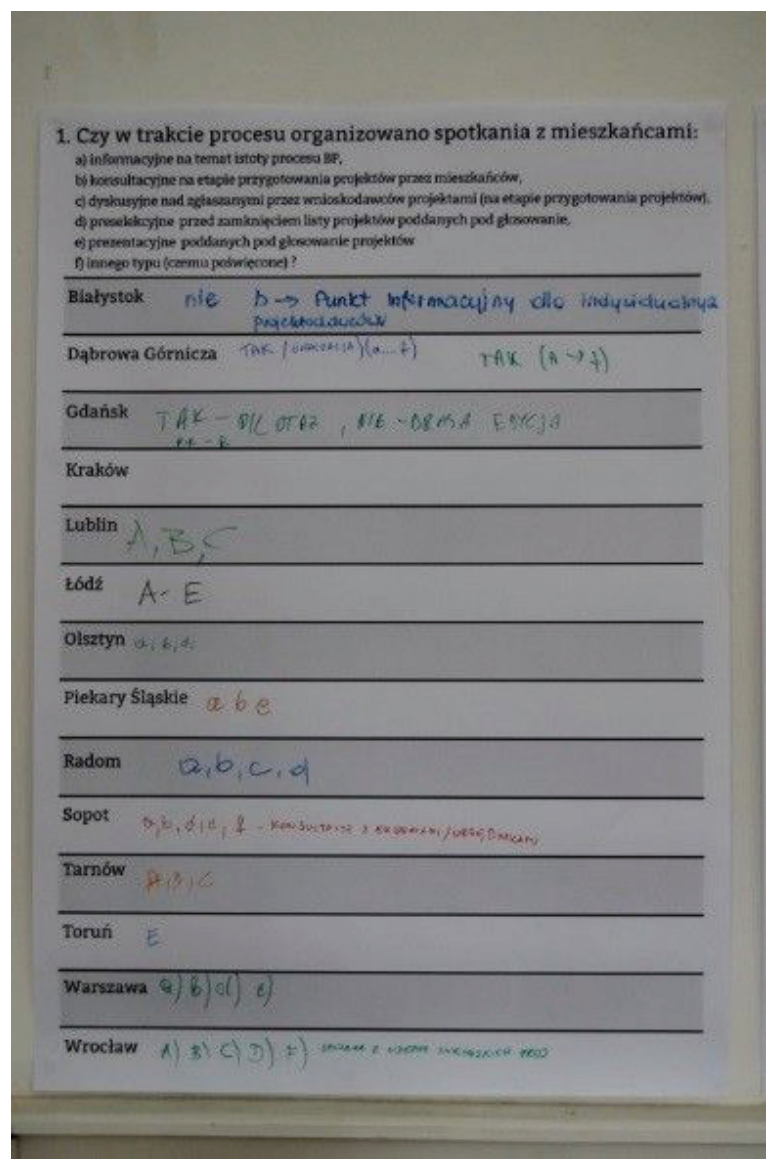

The checklist comes to life in one of the opening activities of the seminar. When giving the answers, participants not only do a 'self-diagnosis' but also inscribe their embodied experiences into propositional accounts (Figure 5). In other words, they make their practices (or a lack of them) visible and comparable; an imprint on flat surface, as Latour would have it (Latour, 1983, p. 164). Moreover, the participants take a lot of interest in seeing 'how it's done' in other places, often discussing particularly intriguing topics with each other, looking for advice and inspiration. They enact their knowledges: share experiences, bring back memories, formulate future objectives, justify choices and test their worldviews. Importantly, most of the times, they do so with reference to the checklist, or namely, within what the knowledge package proposes. 
Fig. 5: A discussion over answering the questions from checklist

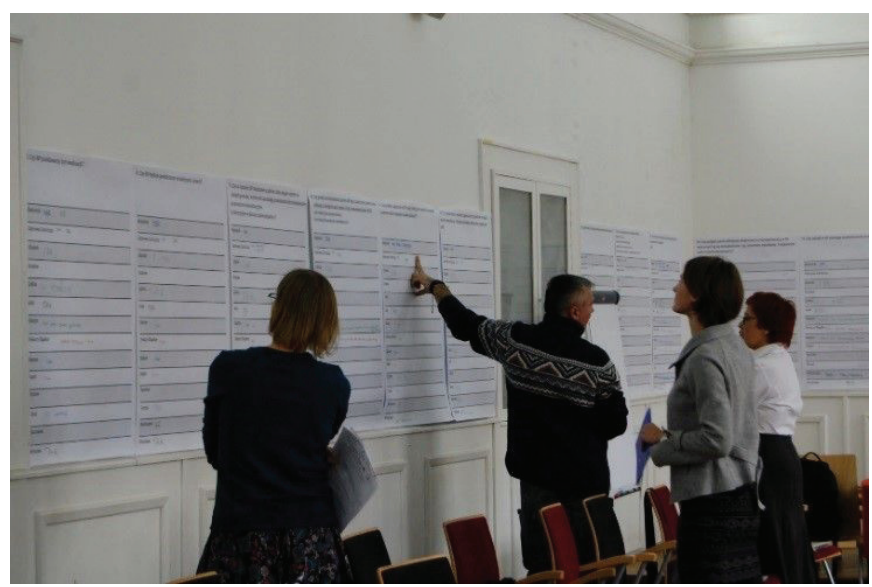

Once completed, the checklist stays there. Thanks to its availability, it becomes an object and an incentive for constant commentaries in public (Figure 6). Particularly, the moderators have a great tool at hand: a complete checklist provides a host of examples at a glimpse of an eye whilst, at the same time, indicating the exact places and solutions that require some reconsideration. The moderators can illustrate the claims presented during the seminar and specify parameters of the hinterland for running the seminar and other future activities in the project.

Fig. 6: The checklist as a 'silent participant' ready to be brought up

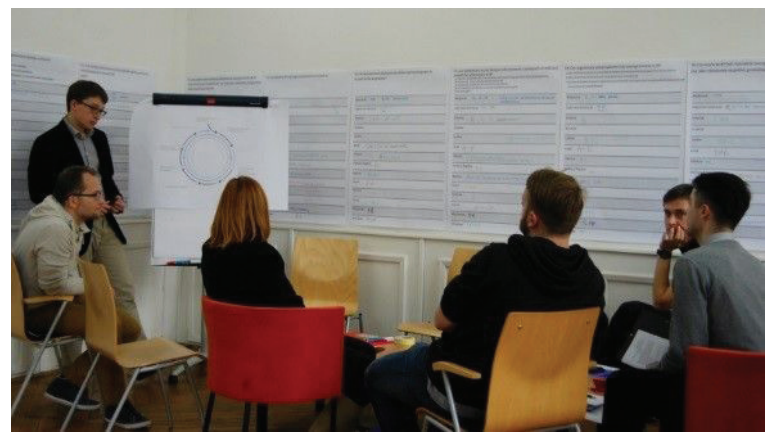

Altogether, the checklist is not merely a means of diagnosing the state of the art. It directs the processes of enacting the knowledges in a subtle, transparent way by posing the questions that are adequate within the package. Thus, it encourages enactments of knowledges around the participatory budget that is possible within the knowledge package from Standards...

\section{... and back to documents and devices}

As stated, the success of knowledge package depends largely on how well it fits within people's beliefs and practices as well as the organisational cultures in which they work. The translations need to ensure that a knowledge package stays workable without the direct involvement of Shipyard; it has to be able to 'act at a distance' (Latour, 1992). In the simplest sense, the model proposed in the base document has to be legally acceptable. More importantly, the more comfortable and effortless the future enactments are, the more probably they will become part of a daily routines. Hence, the knowledge package from the base documents has to 
be translated further into other documents of formal and informal nature as well as various devices and tools. These encompass guidelines and reports, official regulations, sets of ready-to-use research tools, online search engines, Internet platforms for managing communication with the citizens and so on.

A significant part of the project investigated has been devoted to preparing a series of publications complimentary to Standards... They are supposed to provide more information and tips on participatory budgeting in line and with explicit reference to the model proposed in the base document. The series includes a publication on conducting evaluation, an overview of IT solutions used in participatory budgeting outside Poland as well as the so-called tool-box with a detailed review of practices and concrete actions that can be undertaken on each stage of the procedure. Altogether they create a varied, action-oriented body of good practices, examples, citations of existing regulations and legal formulations, research tools and so on.

The contents that the documents provide reflect the embodied and inscribed knowledges of their contributors. The publications accompanying Standards... were created by Shipyard members with partners from the project, including a foreign academic institution. For a general scarcity of good practices in IT applications for participatory budgeting in Poland, the summary was prepared by a Spanish partner. Moreover, since the announcement of Standards..., various knowledges have developed. Throughout the seminars and other project activities, Shipyard members became familiar with a great range of situations and problems from various municipalities, thus enlarging their own embodied expertise. This allowed them to recognise the hinterland in a more detailed manner than before. For instance, the decision to write a separate publication concerning evaluation resulted from the observed gaps in knowledge and skills on this matter amongst project participants. Also, the embodied experiences of Shipyard members translated into the publications, especially into the tool-box. At some point of the project, the authors themselves expressed the feeling that they already knew so many concrete solutions, by-passes, techniques and so on, it would have been worthy to bring them together and share with other people.

Moreover, since the release of Standards..., the very number of participatory budgets was constantly growing. Eventually, there was a variety of documents that could have been cited and still supported the knowledges from the base document. The list of recommended readings and references provided in the tool-box publication was divided into three parts: general information on participatory budgeting (mostly identical to those from Standards...), sample regulations and sample reports from evaluation research from a range of Polish municipalities. All of them were available online, as the bibliography showed.

Another series of translations of the knowledge package from base document took place within an extensive research project concerning participatory budgeting across Poland. As described in the example with checklist, the most transferable elements of knowledge package have been turned into a series of questions. After the seminars, they are further elaborated and turned into an online questionnaire for municipalities. Although the questionnaire covers only the crucial and most determinable elements of the knowledge package, the process of data collection proves fairly lengthy and complicated. The knowledges inscribed under the questions turn out to be hard to enact by civil servants, mainly for lack of available data (or rather, complimentary inscribed knowledges) in their offices. Even though the online survey can be accessed several times without losing previous answers, many questionnaires remain unfinished. Finally, some officials need assistance in filling in the answers, which means that the knowledges inscribed are further enacted in interaction between Shipyard members and respondents.

Most importantly, the questionnaire measures only what is compatible with Standards..., not what the municipalities regard as specific for a participatory budget. This should not give any false impression that such data is useless or that there occurs any kind of mistake or manipulation. In fact, any kind of survey acts this way: reinforcing and somewhat accustoming the framework from which it originates (see Law, 2008). Moreover, the previously available sources of information often delivered data that was chaotic and incommensurable. Most likely, it could have been flawed for the fact that its collection was not structured. It probably consisted in collecting evidence that public offices themselves had made available and that pertained to different topics and responded to varying criteria. The fact that Shipyard draws on the knowledge packages from the base document grants coherence and repeatability to the whole research process and, therefore, increases chances that the survey's results will become a useful, reliable tool for diagnosing and comparing.

The survey does not, however, serve to produce a one-off report stating the participatory budgeting state of the art. The data collected is made available on a specially designed website in researchable files (including those with raw statistical data) and through a tailor-made comparing device. The website is quite likely to become a popular source of information for journalists, academics and the practitioners themselves, not only for the character of the data provided (structured and comparable) but also thanks to the convenient appliances for its presentation. Interestingly, many civil servants have been convinced to fill the questionnaire only at the 
information that all the data collected would be made available on a special website, thus allowing them to redirect anyone inquiring their participatory budgeting in future. In other words, the promise of producing a chain of translations - from their enactments and inscriptions in the questionnaire into another more reproducible and shareable source - has contributed to winning allies for the whole process. Eventually, the origins of data will probably disappear in the course of future citations and applications.

\section{CONCLUSIONS}

The purpose of this paper is to provide an argument in favour of understanding knowledge primarily in terms of its performativity rather than the traditional static vision of discovery and implementation (for more see Kołtun, 2015). In the article, I have presented the case of producing and translating various types of knowledge with the objective of improving participatory budgeting in Polish municipalities. From the start, it is clear that the elements that are traditionally defined as internal or external to knowledge here become inextricably intermingled and mutually constituting. The story presented here does not consist in a series of steps presenting subsequent applications and refinements of knowledge understood as a primarily descriptive, merely textual product. Instead, it takes advantage of a holistic approach towards organisations and socio-material realities, highlighting the processual, pragmatic and messy knowledge tinkering in shifting settings. This way the incessant 'chaos-management' proves much more important than releasing topquality products that, simply, do not work. The implications for managing knowledge envisioned this way are far reaching.

The very knowledge package that is supposed to become part of daily practice of the civil servants includes definitions and conceptual ideas, recommendations and tips towards future practices as well as a body of values that justify and guide the directions proposed. Furthermore, it becomes successful only in the course of complex, multiplying translations that, eventually, entail much more than a reform of the existing situation; rather, they consist in performing the knowledge package and reconstructing the setting for its success. In the case presented, knowledge translations exceed far beyond the work on documents, which long enough have remained at the centre of attention of both philosophy of science and policy studies. As Freeman and Sturdy emphasise, all three phases of knowledge - the enacted, inscribed and embodied - are indispensable here. More importantly, they are mutually constitutive, yet, none is identical with another. Every translation is productive - it consists in linking some elements together and transforming them all at the same time.

Basically, embodied knowledges are much more than what is commonly labelled 'know-how'. The practical competences are at least equally important to the worldviews, beliefs and experiences of people. Embodied knowledge grows quickly and often unnoticeably but is hard to unearth and conceptualise. Also, it always remains person dependent, and for that reason, the embodied knowledges, which are collectively enacted, are crucial for generating ideas but not sufficient to legitimise them (see Maybin 2015). All these features and difficulties have been apparent in seminars organised by Shipyard during which the participants were supposed to acquire some new (although adequately oriented) experiences and ideas but, at the same time, situate them within their existing worldviews.

Next, the knowledges inscribed in documents and devices allow surpassing the constrains of embodiment. They can be shared and transferred without loss of information, thus supporting the coordination of people across time and places. At the same time, they create opportunities to enact knowledges inscribed, especially if the devices are convenient and time saving. Finally, they can serve as tools for control and disciplining for they promote transparency, standardisation and comparability. Largely, documents and devices reinforce what Latour calls 'interobjectivity' (1996): they sustain the impression that realities are external, independent and common for the individuals, whilst erasing their historicity, contingency and dependence on human action. As described earlier, a variety of publications and devices produced in the course of the project may serve all these purposes - provide opportunities, impose actions and accustom the knowledges proposed as quite obvious and 'ready to hand'.

Finally, the enacted knowledge is the most difficult to grasp. Two former translations support future enactments that would be effortless for individuals and well embedded in organisational cultures of the offices, either in collective action or by use of the technical devices. Paradoxically, in the case presented here, the less visible and troublesome it is, the better it works. For eventually, the initially launched knowledges are supposed to turn into a fairly coherent, non-imposing framework for thinking and acting with regard to future participatory budgeting. The more stabilised and extensive network of people, documents and devices, the more successful an elemental knowledge package, together with the model proposed, become. 


\section{ACKNOWLEDGEMENT}

An earlier version of this article was presented at 10th International Conference in Interpretive Policy Analysis, University of Lille 2, 8-10 July 2015. I would like to thank to two anonymous reviewers as well as Professor Hal Colebatch, Professor Agnieszka KolasaNowak and Professor Zbysław Muszyński for their extensive advice on how to refine this paper.

\section{REFERENCES}

Austin, J. L. (1975). How to DoThings With Words. Oxford: Clarendon Press.

Barad, Karen. (2003). Posthumanist Performativity: Toward an Understanding of How Matter Comes to Matter. Signs, 28, 801-831.

Bluj, A., \& Stokłuska, E. (2015). Budżet partycypacyjny (obywatelski) krok po kroku. Poradnik dla praktyków (Participatory [Civic] Budgeting Step by Step. A Guidebook for Practitioners). Warsaw: The Unit for Social Research and Innovation 'Shipyard'. Accessed 1 May 2016. http://stocznia.org.pl/ app/uploads/2016/o1/BP_krokpokroku.pdf

Callon, M. (1986). Some elements of a sociology of translation. Domestication of the scallops and the fishermen of St Brieuc Bay. In Law J. (Ed.), Power, Action and Belief: A New Sociology of Knowledge (pp. 196-233). London: Routledge \& Kegan Paul.

Charmaz, K. (2006). Constructing Grounded Theory: A Practical Guide through Qualitative Analysis. Thousand Oaks, CA: Sage.

Clarke, J., Bainton, D., Lendvai, N., \& Stubbs, P. (2015). Making Policy Move. Towards a Politics of Translation and Assemblage. Bristol: Policy Press.

Colebatch, H. K., Hoppe, R., \& Noordegraaf, M. (2010). Understanding Policy Work. In Colebatch, H. K., Hoppe, R., \& Noordegraaf, M. (Eds.), Working for Policy (pp. 11-25). Amsterdam: Amsterdam University Press.

Freeman, R. (2009). What is 'translation'?. Evidence \& Policy: A Journal of Research, Debate and Practice 5/4: 429-447.

Freeman, R., \& Sturdy, S. (2015a). Introduction: Knowledge in Policy - Embodied, Inscribed, Enacted. In Freeman, R., \& Sturdy, S. (Eds.), Knowledge in Policy. Embodied, Inscribed, Enacted (pp. 1-17). Bristol: Policy Press.

Freeman, R., \& Sturdy, S. (2015b). Knowledge and Policy In Research and Practice. In Freeman, R., \& Sturdy, S. (Eds.), Knowledge in Policy. Embodied, Inscribed, Enacted (pp. 201-218). Bristol: Policy Press.

Glab, V., \& Parés, M. (2015). Narzędzia ICT w procesach budżetu partycypacyjnego. [ICT Tools in the Processes of Participatory Budgeting]. Warsaw: The Unit for Social Research and Innovation 'Shipyard'. Accessed 1 May 2016. http://stocznia.org.pl/app/uploads/2016/01/ Narze\%CC\%A8dzia-ICT-w-procesach-budz\%CC\%87etupartycypacyjnego.pdf

Kębłowski, W. (2014). Budżet partycypacyjny. Ewaluacja. (Participatory Budgeting in Poland: an Evaluation). Warsaw: Instytut Obywatelski. Accessed 1 January 2017. http://www.instytutobywatelski.pl/wpcontent/uploads/2014/07/budzet-partycypacyjny-web.pdf
Kołtun, A. (2015). Can Knowledge be (a) Performative? Performativity in the Studies of Science. Lublin: Wydawnictwo UMCS.

Latour, B. (1983). Give Me a Laboratory and I will Raise the World. In Knorr Cetina, K. \& Mulkay, M. (Eds.), Science Observed. Perspectives on the Social Studies of Science (pp. 141-170). Thousand Oaks, CA: Sage.

Latour, B. (1992). Where Are the Missing Masses? The Sociology of a Few Mundane Artifacts. In Bijker, W. E. \& Law, J. (Eds.), Shaping Technology/ Building Society: Studies in Sociotechnical Change (pp. 225-258). Cambridge, Mass.: MIT Press.

Latour, B. (1996). On Interobjectivity. Mind, Culture, and Activity: An International Journal Traduction, 3/4, 228-245.

Latour, B. (1999). Pandora's Hope. Essays on the Reality of Science Studies. Cambridge, MA, London, UK: Harvard University Press.

Latour, B. (2005). Reassembling the Social. An Introduction to ActorNetwork-Theory. Oxford: Oxford University Press.

Law, J. (2004). After Method. Mess in Social Science Research. London, New York: Routledge.

Law, J. (2007; draft version). Actor Network Theory and Material Semiotics. Accessed 11 November 2014. http://www.heterogeneities. net/publications/Law2007ANTandMaterialSemiotics.pdf

Law, J. (2008; draft version). Seeing Like a Survey. Accessed 11 November 2014. http://www.heterogeneities.net/publications/ Law2008SeeingLikeASurvey.pdf

Maybin Jo. (2015). "'We Know Who to Talk to': Embodied Knowledge in England's Department of Health". In Freeman, R., \& Sturdy, S. (Eds.), Knowledge in Policy. Embodied, Inscribed, Enacted (pp. 79-102). Bristol: Policy Press.

Ostrowski, Ł., \& Rudnicki, R. (2015). Jak ewaluować budżet partycypacyjny (obywatelski)? (How to Evaluate a Participatory (Civic) Budget?). Warsaw: The Unit for Social Research and Innovation 'Shipyard'. Accessed 1 May 2016. http://stocznia.org.pl/app/uploads/2016/o1/Jak-ewaluowac-BP-BO.pdf

Peck, J., \& Theodore, N. (2015). Fast Policy. Experimental Statecraft at the Thresholds of Neoliberalism. Minneapolis: University of Minnesota Press.

Pickering, A. (1992). From Science as Knowledge to Science as Practice. In Pickering, A. (Ed.), Science as Practice and Culture (pp. 1-26). Chicago, London: University of Chicago Press.

Pickering, A., \& Stephanides, A. (1992). Constructing Quaternions: On the Analysis of Conceptual Practice. In Pickering, A. (Ed.), Science 
as Practice and Culture (pp. 139-167). Chicago, London: University of Chicago Press.

Rouse, J. (2014). Scientific Practice and the Scientific Image. In Soler, L., Zwart, S., Israel-Jost, V., \& Lynch, M. (Eds.), Science After the Practice Turn in the Philosophy, History, and Social Studies of Science (pp. 277294). London, New York: Routledge.

Ryle, G. (1949). Knowing How and Knowing That. In Gilbert Ryle: Collected Papers. Vol. 2, (pp. 212-225). New York: Barnes and Noble.

Standardy Procesów Budżetu Partycypacyjnego w Polsce (Standards for the Processes of Participatory Budgeting in Poland). (2014). Various convenors. Warsaw: The Unit for Social Research and Innovation 'Shipyard'. Accessed 1 January 2016. http://stocznia.org.pl/publikacje/ standardy-procesow-budzetu-partycypacyjnego-w-polsce/
Szaranowicz-Kusz, M. (2016). Participatory Budgeting in Poland. Infos, 1/205, 1-4. Accessed 1 January 2017. http://orka.sejm.gov.pl/WydBAS. nsf/o/DFD81CE49C17B3D6C1257F50005058B1/\$file/Infos_205EN.pdf

Sześciło, D. (2015). Participatory budgeting in Poland. Quasi-referendum instead of deliberation. Hrvatska i komparativna javna uprava, 2, 373388.

Wehling, P. (2006). The Situated Materiality of Scientific Practices: Postconstructivism - a New Theoretical Perspective in Science Studies?. Science, Technology \& Innovation Studies, 1, 81-100.

Yin, R. (2003). Case study research, design and methods. Newbury Park: Sage Publications. 